Aletria, Belo Horizonte, v. 28, n. 3, p. 63-81, 2018

\title{
Milton's Prose Works in the Hispanophone World
}

\section{As obras em prosa de Milton no mundo hispanofônico}

\author{
Angelica Alicia Duran \\ Purdue University, West Lafayette, Indiana / Estados Unidos \\ duran0@purdue.edu
}

\begin{abstract}
This study of key instances of the circulation and reception of the prose works associated with "John Milton, Englishman" in the Hispanophone world demonstrates the active contributions of Hispanophone readers in constructing the works of this canonical author as world literature. Showcased here the anti-Spanish propaganda piece A Declaration of His Highnes, by the Advice of His Council Setting Forth, on the Behalf of this Commonwealth, the Justice of Their Cause against Spain published simultaneously in Latin, English and Spanish; the Latin defense of the English regicide Pro populo Anglicano defensio; and the Anglophone pamphlet against pre-publication censorship Areopagitica. The works are discussed in their original languages and in Spanish translation, as well as in the context of Spain and the Americas.
\end{abstract}

Keywords: John Milton; reception; prose; Latin America; Spain; Spanish Catholic Inquisition.

Resumo: Este estudo de momentos-chave da circulação e da recepção dos textos em prosa associados a "John Milton, Englishman" no mundo hispanófono demonstra as vigorosas contribuições dos leitores hispânicos na construção dos textos deste autor canônico enquanto literatura universal. Os objetos deste estudo são a peça de propaganda antiespanhola A Declaration of His Highnes, by the Advice of His Council Setting Forth, on the Behalf of this Commonwealth, the Justice of Their Cause against Spain, publicada simultaneamente em latim, inglês e espanhol; a defesa latina do regicídio inglês Pro populo Anglicano defensio; e o panfleto anglófono contra a censura de pré-publicação Areopagitica, em suas línguas originais e em espanhol, na Espanha e nas Américas.

Palavras-chave: John Milton; recepção; prosa; América Latina; inquisição católica espanhola. 
During its heyday from the early sixteenth century to the midnineteenth century, the Spanish Catholic Inquisition's series of indexes of proscribed works and heretical authors, the Index librorum prohibitorum, contributed to suppressing specific sets of works. Somewhat ironically, today it serves as an often-neglected resource for researchers seeking evidence for the likelihood of the presence of specific works in Spanish territories and the nature of Spanish reading habits. It is indeed in the 1707 Marín Index, published thirty-three years after Milton's death, that we find two prose works associated with Milton first published during the years in which Milton served as Secretary of Foreign Tongues (16491660). ${ }^{1}$ This discussion of these works draws out the implications for conceptualizing and articulating authorship in direct relation to early modern Spanish reader response and subsequent responses.

\section{Milton's name with the Manifiesto del Protector and on the Spanish Catholic indexes}

A set of works whose authorship has not yet been and may never be assured to be that of Milton, in whole or in part, but which often circulates under Milton's name, through today, is the Latin Scriptum Dom: Protectoris [...] in quo hujus reipublic causa contra hispanos justa esse demonstrator, Anglophone A Declaration of His Highnes, by the Advice of His Council Setting Forth, on the Behalf of This Commonwealth, the Justice of Their Cause against Spain and Hispanophone Manifiesto del protector de Inglaterra [...] declarando de fabor desta Republica la justicia de su causa contra España, all published by the press of Henry Hill and John Field in London in 1655. ${ }^{2}$ The triad of works justifies the English Commonwealth's attack on Spain's Caribbean colonies, often referred to as Cromwell's Western Design. The simultaneous trilingual publication corroborates the rise in the seventeenth century of the use of vernaculars alongside and eventually over Latin, which had for centuries served as the international language of elite readers in Europe. The matter

\footnotetext{
${ }^{1}$ The indexes are commonly referred to by their year of publication and the name of the main inquisitor at that time. I use this terminology.

${ }^{2}$ For further discussion on the context of this work, see SAUER. Toleration and Translation.
} 
of language-use and translation is of significance in relation to Milton's prose, as discussed later.

None of the copies of the 1655 versions with which I have conducted primary research include Milton's name, and the work remains of dubious authorial attribution. ${ }^{3}$ The attribution to Milton in the publication of a new English version of the work in 1738 provides clear signs that the publishing house of Thomas Birch believed that tethering this repackaged work to Milton's name, whose position as a canonical author had slowly but surely become established in England, would generate an audience for it and that adding Miltonic fuel to the renewed efforts of King George II (r. 1727-1760) to wrest American holdings from Spain would heighten anti-Spanish sentiment-Milton expressed clear anti-Spanish sentiment in many of his prose works.

Even if Milton had prepared the prose work, however, he did so in fulfillment of his secretarial role for a corporate, governmental entity. Thus, the most accurate attribution is the other common authorial attribution of the work in contemporary catalogues, "England and Wales. Lord Protector (1653-1658: O. Cromwell)". The Hispanophone version is listed for the first time in the Spanish Catholic Inquisition's series in the "M III. Class" section of the 1707 Marín Index absent of any authorial ascription, as is common in that section: "*Manifiesto del Protector de Inglaterra $[. .$.$] causa contra España". { }^{4}$ Class III is for anonymous and corporate works, either prohibited or requiring expurgation, in contrast to Class I entries, which consist of the names of heretical authors whose entire oeuvre is prohibited, and tampered works by Christian authors that

\footnotetext{
${ }^{3}$ MILTON. Complete Prose Works of John Milton, v. 5, p. 711-712.

${ }^{4}$ SARMIENTO; MARÍN. Novissimus librorum prohibitorum et expurgandorum, v. 2, p. 80. The text also appears in the CONSUELO DE INQUISICIÓN. Indice general de los libros prohibidos y mandados expurgar, p. 213. For the difficulty of definitively ascribing Scriptum Dom. Protectoris / A Declaration / Manifiesto to Milton, see FALLON. Milton in Government, p. 99. For the process by which the Cromwellian Declaration came to be attributed to Milton in a later season of anti-Spanish agitation, see VON MALTZAHN. Acts of Kind Service, p. 249. For its multilingual dimensions, see DURAN. Not either/or but rather both/and: Both Material and Electronic Archival Research in both English and Comparative Literature Graduate Courses.
} 
need expurgations; ${ }^{5}$ and Class II entries, works requiring expurgation or careful attention. ${ }^{6}$ The listing of the Hispanophone version indicates both the likelihood of this, rather than the Anglophone or Latin versions, being either present within Spanish borders or being perceived of as particularly incendiary, a commonsensical conclusion given the accessibility of the Hispanophone version to a wider range of Spanish readers.

The absence of any authorial ascription to Milton in the 1707 Marín Index is particularly conspicuous because it is in the same index that Milton's name first appears in the inquisitorial series, in the Class I section and as a heretic, rather than as an author whose works have been tampered with: “*Ionnnes Milthonivs, Anglus, Hæ- | retic. Pro Populo Anglicano Defenfio, con- | tra Claudij Salmasij Defenfionem Regiam. | Londini". ${ }^{7}$ Both in isolation and in consideration of the Class III entry of the Manifiesto del protector de Inglaterra [...] contra España, the presence of Pro populo conveys much about the nature of the prose

${ }^{5}$ SARMIENTO; MARÍN. Novissimus librorum prohibitorum et expurgandorum, v. 1, p. 1. For help with this and the next translations from the Latin, I thank John Hale. The specific wording is as follows: "First class of authors of damned memory, whose published and forthcoming Works are prohibited: but individual works [of those authors] are permitted which have been expurgated or else because they seem harmless" ["Prima classis auctorum damnatæ memoriæ, quorum Opera edita, \& edenda sunt prohibita: nisi expurgata, aut, quod videantur innoxia, nominatum permittantur"].

${ }^{6}$ SARMIENTO; MARÍN. Novissimus librorum prohibitorum et expurgandorum, v. 1, p. 27. The specific wording is as follows: "The second class, in which the books of certain authors are either prohibited or else expurgated or else are marked by the addition of a caution or an explanation" ["Secunda classis. In qua certorum avctorum libri aut prohibentur, aut expurgantur, aut cautione, explicationeve adhibita, notantur"]. The Class II section of the Index librorum prohibitorum, ac expurandorum novissumus. Pro universis hispaniarum regnis serenissimi Ferdinand VI. Regis Catholici (v. 2, p. 857) is where we find, for example, Don Quixote and directions regarding one passage from the novel: "MIGUEL de Cervantes. | Its second part of Don Quixote, chap. | 36. in the middle, erase the works of charity that are done lazily do not have merit, they are worth nothing" ["MIGUEL de Cervantes. | Su segunda parte de Don Quixote, cap. | 36. al medio, borrese las obras de caridad que se hacen floxamente, no teinen merito, ni valen nada"]. All English translations of Spanish originals are mine unless otherwise noted. In my transcriptions included in the endnotes, I maintain all orthographic particularities of the Spanish originals.

${ }^{7}$ SARMIENTO; MARÍN. Novissimus librorum prohibitorum et expurgandorum, v. 1, p. 660. 
work and about its reception and circulation in Spain, as in much of Europe. This Latin work, which justifies the regicide of England's King Charles I in January 1649, was incendiary enough in any language, in many places including Spain, and for nearly half a century after its initial publication. Well before its inclusion in the 1707 Marín Index, it was "among the books condemned to the fire in Paris [...] in 1651" and by order of the "Parlement de Toulouse" in the same year;" and upon the English Restoration in 1660, the English House of Commons ordered it burned, along with Milton's Eikonoklastes. ${ }^{9}$ Spain's proscription, thus, was in accord, if belatedly, with that of a large European community. The Latin Pro populo is of certain authorial ascription and Milton's name appears on the original. Nonetheless, the entry is technically misplaced on the 1707 Marín Index. For, in the work Milton asserts that he wrote the work as a corporate spokesperson for the Interregnum government: "the leaders of our state have authorized me to undertake this task". ${ }^{10}$

The works also tell us something about Milton's authorial name more specific to the Anglophone and Hispanophone worlds. The proscribed status of Pro populo in England in the seventeenth century and in Spain starting in the eighteenth century reminds us of the sharp change in the reception of the once-despised Milton in his homeland of England, not just as a canonical poet but also as a writer of political prose who merits affiliation. ${ }^{11}$ In his 1738 republication of a new Anglophone version of Scriptum / A Declaration / Manifiesto, Birch justifies his authorial ascription of the work stating that "This piece, from the peculiar Elegance of the Stile, appears to have been drawn up in Latin by our Author [Milton], whose Providence it was, as Secretary to Cromwell" (emphasis mine). ${ }^{12}$ That affiliating our contrasts sharply with the Spanish

\footnotetext{
${ }^{8}$ BENITEZ. Presencia de Milton en la literatura española, p. 32; REDMAN. Major French Critics of the Nineteenth Century, p. 1.

${ }^{9}$ FRENCH. Life Records of John Milton, v. 4, p. 329.

${ }^{10}$ MILTON. Complete Prose Works of John Milton, v. 4, p. 305.

${ }^{11}$ For the slow growth of Milton's canonicity in England then elsewhere, see FLANNAGAN. "The World All Before [Us]": More than Three Hundred Years of Criticism.

${ }^{12}$ BIRCH. An Account of the Life and Writings, p. xxxiv. For the republication of the work itself, see ENGLAND AND WALES. A Manifesto of the Lord Protector. I am grateful to the Purdue Archives and Special Collections for access to its copy of A Manifesto.
} 
Catholic Inquisition's Othering "Anglus". Further, the inclusion by the Spanish Catholic Inquisition of the name of "John Milton, Englishman," as his name appears on the originals of some of his works, contributed actively to the construction of Milton's prose and by extension an English work as world literature. His name and works merited inclusion in the series of indexes not only for their heretical nature but also for the renown of the author. By contrast, the works of Milton's near contemporary, the incendiary playwright, poet and government agent Christopher Marlowe were burned in 1599 as part of England's Bishop's Ban, but neither his name nor works appear on the Spanish Catholic Inquisition or Roman Catholic Inquisition lists. Oliver Cromwell's name is also absent. Finally, the presence of Pro populo in the Class I Milton entry and Manifiesto in Class III of the 1707 Marín Index, leads to three valid hypotheses, the evidence for any of which may no longer exist due to the Spanish Catholic Inquisition's intentional destruction of documentation of its decision-making processes or, simply, unintentional decomposition of archival materials: ${ }^{13}$ first, the Spanish Catholic inquisitors were unaware of the potential hand that Milton played in Scriptum / A Declaration / Manifiesto; second, the Spanish Catholic inquisitors knew of the differing levels of authorial ascription and thus actively placed the two works in appropriately different sections to enable the easiest detection of the proscribed works; and third, this is yet another indication of discrepancies to be found in the Spanish Catholic indexes and to be expected in any work compiled by many hands over centuries.

Today, the discrepancy calls us to reconsider Pro populo as a corporate work. In recent years, innovative work has emerged in Shakespeare studies from investigating the collaborative authorship of works that have circulated under only Shakespeare's name, as well as other works. The result is not to chip away at Shakespeare as "genius", but rather to discover accurate creative practices at the time of the sharp

\footnotetext{
${ }^{13}$ The degradation of archives extends through today, as evinced by the formal request in 2017 by the Latin American Studies Association for the Spanish government to provide funding to reverse "the alarming decrease in the number of workers" trained to preserve, access, and disseminate the rich collections of the General Archive of the Indies, or AGI, in Seville, Spain.
} 
rise of English literature. ${ }^{14}$ In relation to Milton's works, an eye on collaboration promises to be similarly generative and perhaps uniquely so in terms of Disability Studies, given that the 1650 s constituted the completion of Milton's slow-onset blindness and that Milton praises the accommodations provided him in yet another prose work, Defensio Secunda (1654): "the chief men in the state do not desert me". ${ }^{15}$

I end this section with an important coda that involves the subsequent two major indexes of the Spanish Catholic Inquisition: the 1790 Rubín Index and 1844 Palacios Index. The Milton entry in the 1790 Rubín Index -a very sparse volume- contains no works, only Milton's name, national affiliation and category: "Milthonius (Joan.), Angl. I. cl." 16 The Milton entry in the 1844 Palacios Index lists two works: "+ Miltonus (Joannes). Litteræ psendo-sena- | tus anglicani, Cromwellii, reliquorumque | perduellium nomine, ac jussu consciptæe, | (decr. 22 decembris 1700). | +-- Il paradiso perduto: poema inglese, tra- $\mid$ dotto in nostra lingua da Paolo Rolli (decr. | 21 de januarii 1732)". ${ }^{17}$ These works are best described as associated with rather than authored by Milton: Literae pseudo-senatus (1676) is a posthumously-published "surreptitious publication of dispatches written by Milton in his capacity of Latin secretary to the Council of State, between the years 1649 to 1659 "; ${ }^{18}$ and, as a translation, Il paradiso perduto would have warranted regular users of the Spanish Catholic indexes, and should warrant us today, to reserve judgment on wherein lay the heresy: the author, the poem, an insidious Italophone translator, unintentional corruptions in the Italophone translation, or the collaborative creator(s) of the original or Italophone editions' paratexts. ${ }^{19}$ While it is, at last, in the midnineteenth century index that a poetic work makes its way onto a Milton entry, none of the indexes identify Milton as a "poeta." The absence of

\footnotetext{
${ }^{14}$ For the critical implications of the figuration of Shakespeare as genius, see especially BLOOM. Genius: A Mosaic of One Hundred Exemplary Creative Minds.

${ }^{15}$ MILTON. Complete Prose Works of John Milton, v. 4, p. 591.

${ }^{16}$ RUBÍN DE CEVALLOS. Indice ultimo de los libros prohibidos y mandados expurgar, p. 182.

${ }^{17}$ CONSUELO DE INQUISICIÓN. Indice general de los libros prohibidos y mandados expurgar, p. 230.

${ }^{18}$ See PURDUE University Libraries.

${ }^{19}$ For a discussion of the Rolli and other Italian translations, see BORGOGNI. "Censur'd to be much inferiour": Paradise Lost and Regained in Italian.
} 
such an identifier -used for well over one hundred other writers in, for example, the first volume in which Milton's name appears- substantiates Neil Forsyth's observation that, while Anglophone readers have known Milton as primarily a great English epic writer, his renown outside the Anglophone world has rested on his prose. ${ }^{20}$

\section{Milton's Areopagitica, its French imitation, and its Spanish translations}

Before he became Secretary of Foreign Tongues, "Mr. John Milton" directed his pamphlet against pre-publication censorship Areopagitica (1644) to "the Parlament of England" as a private citizen driven to "advance the publick good" and "promote" his "Countries liberty". ${ }^{21}$ Yet, Milton's Areopagitica has spoken powerfully to individuals in many places and in many times of personal and political transformation. While reading habits are even harder to gauge accurately than book circulation, data indicates that Areopagitica may be the most translated prose work by Milton, in turn indicating extensive interest in the work. ${ }^{22}$ In tracing Areopagitica's circulation in the Hispanophone world, the forces that we find at the forefront, even before the demise of the Spanish Catholic Inquisition at the beginning of the mid-nineteenth century, are Francophilia and, later, printing presses.

As late as 1890, in justifying publishing his edition of Areopagitica, the U.S. professor of Spanish and French at Harvard, co-founder of the Modern Language Association, internationally famed writer, U.S. Ambassador to Spain (1877-1880) and U.S. Minister to England (18801885), James Russell Lowell agreed with David Masson, who in his nearly coeval magisterial biography of Milton (1859-1894) states that, "There is no trustworthy evidence that the 'Areopagitica' produced any

\footnotetext{
${ }^{20}$ FORSYTH. Sublime Conversations.

${ }^{21}$ MILTON. Areopagitica (1644), p. title-page, 1.

${ }^{22}$ It is in the twentieth century that we find a peak in translations of Areopagitica in the cross-sampling I gathered from the contributors of Milton in Translation: into German, translated by Richard Roepell (1851), Italian by Salvatore Breglia (1933), Dutch by Horace Shipp (1945), Japanese by Seiichi Ueno, Kenji Ishida, and Shingo Yoshida (1948), Chinese by Wu zhi Chun (1958), Estonian by Hanno Rajandi (1987), Serbian by Darko Bolfan (1990), Portuguese by Felipe Fortuna (1999), Arabic by Mohamed Enani (2009), Polish by Joanna Rzepa (2012), and, as discussed further in this essay, translated into Spanish by Catalonia’s Josep Carner (1941) and Mexico’s Mario Murgia (2014).
} 
immediate effect". ${ }^{23}$ Russell further avers that, more than two and a half centuries later, "it cannot be said that the prose works of Milton have ever been in any sense popular or read by any public much more numerous than the proofreader". ${ }^{24}$

These and later critical assessments about interest in Areopagitica do not apply to the non-Anglophone world, beginning in the lateeighteenth century. Among many indications from France is the imitation of Areopagitica by Honoré-Gabriel de Riqueti, comte de Mirabeau (174991), the Francophone On the Liberty of the Press, an Imitation of the English [Work] by Milton [Sur la liberté de la presse, imité de l'anglois, de Milton] (1788), published in the months preceding the start of the French Revolution in 1789. This work resides in many Latin American libraries. In Mexico, for example, the work can be found in the first circulating library in the Americas, the Biblioteca Palafoxiana in Puebla, in the eastern State of Veracruz, and in the public archives of the State of Oaxaca, in western Mexico; no edition or imitation of Areopagitica in English, Spanish or any other language resides in these libraries. While literacy rates in Mexico were low throughout the eighteenth and nineteenth centuries, language training in Mexican private and public schools would have rendered French (as well as Spanish, English, and Latin) accessible to the reading elite in Mexico, with Francophilia and the shared language roots of French and Spanish rendering French an attractive language of study. ${ }^{25}$ The case of the beloved president of Mexico of Zapotecan heritage Benito Juárez (1806-1872), educated in the public schools not in the metropolis of Mexico City in the State of Mexico but rather in the State of Oaxaca, is reflective of the educated Mexican elite: he passed his exams for his law degree in Latin and the last book he was reading at the time of his death was in French.

Mirabeau's formulation of Areopagitica as a model for international readers seeking a clarion voice to advance civil liberties, rather than a careful summary of ancient to medieval book censorship and a historical document related to an early modern English policy (which it is also), has been regularly repeated in many quarters. Lowell clearly

\footnotetext{
${ }^{23}$ MILTON. Areopagitica (1890), p. xxxix; MASSON, Life of Milton.

${ }^{24}$ LOWELL. Areopagitica, p. xxxix.

${ }^{25}$ See INSTITUTO Literario. El instituto literario del estado de Mexico en 1870, p. 8; MÉXICO. Legislación mejicana, p. 251-253.
} 
correlates regulations on print circulation in Milton's England during its civil war (1642-1651) and in his beloved U.S. recovering from its civil war: "Those who watched the strange intellectual and ethico-political upheaval in New England fifty years ago will be at no loss for parallels to these phenomena". ${ }^{26}$ Over a hundred years later, María Nieves Saldaña Díaz articulates the prose work's transhistorical, transgeographical relevance when she avers that the "approach that Milton formulates in Areopagitica is as real and current in the Puritan England of 1644 as in the technological and computerized society at the beginnings of the twenty-first century". ${ }^{27}$

Spain's libraries have also left transnational, multi-lingual traces of Areopagitica that indicate the reach and power of presses in shaping reader reception. A few years after Lowell's 1890 edition of Areopagitica gave the work a boost in reception, his Harvard colleague Charles W. Eliot included it in Volume 3 of his highly-influential, 51-volume Harvard World Classics (1909). ${ }^{28}$ A 1965 reprint of that volume is catalogued in the National Library of Spain, as is the earliest listing of Areopagitica in any language in the Library, an Anglophone version from yet another influential mass-market series, Bohn's Standard Library (1848-1853), constituted of approximately 600 titles and named after the British publisher Henry George Bohn. The National Library of Spain also houses the Juan Catalán-Luis Blanco Vila Hispanophone translation of Areopagitica of 1999 but not the first Hispanophone translation of the prose work by Catalonian Josep Carner in 1941, even though Carner's translation remains the most readily available and well-known among Hispanophone readers. The absence of Carner's Hispanophone translation of Areopagitica in the National Library of Spain is suggestive, especially when combined with the fact that it is the sole one to emerge during the period of the totalitarianism of Francoist Spain (1939-1975). ${ }^{29}$ The "well-

\footnotetext{
${ }^{26}$ LOWELL. Areopagitica, p. xix.

${ }^{27}$ SALDANA DÍAZ. En defensa de la libertad de prensa, p. 279. "Los pensamientos que formulase Milton en la Areopagítica son tan reales y actuales en la Inglaterra puritana de 1644 como en la sociedad tecnológica e informatizada de principios del siglo XXI". ${ }^{28}$ Volume 3 contains Areopagitica and OfEducation, along with Francis Bacon's Essays, Civil and Moral and New Atlantis, and Thomas Browne's Religio Medici.

${ }^{29}$ For the case of active state suppression of Milovan Djilas's Serbian translation of Paradise Lost, see STROJAN. Milton in Serbian/Montenegrin: Paradise Lost from behind bars.
} 
known Catalan poet" Carner is regularly characterized as representative of the "Catalonian culture [..., a distinct culture", a culture perceived of as particularly independent amid the predominant Castilian-speaking Ibero-Spanish culture. ${ }^{30}$ The call for Catalonian secession from Spain resurfaced en force yet again in 2014, following Scotland's formal effort to secede from the U.K.

Tempering the possibility of heightening the political frisson we might associate with Carner's Areopagitica is his eclectic group of over twenty translations into Catalan and Spanish, including Alice's Adventures in Wonderland by Lewis Carroll, "Thumbelina" by Hans Christian Andersen and Carner's earliest English-to-Spanish translation The Cricket on the Hearth (in 1902) by Charles Dickens, whose works take the lion's share of Carner's translations. ${ }^{31}$ Amid these less philosophically and politically taxing works is a small cluster of translations into Spanish of serious, liberal works that Carner published through the Mexican press Fondo de Cultura Económica in his later life, when he "was a republican exile in Mexico": ${ }^{32}$ from English, in addition to Milton's Areopagitica, John Locke's Treatise on Civil Government [Ensayo sobre el gobierno civil], Carl Becker's Heavenly City of God of the Eighteenth Century Philosophers [La ciudad de Dios del siglo XVIII] and Charles Cochrane's Christianity and Classical Culture [Cristianismo y cultura clásica]. We are warranted to hypothesize that Carner sought to temper reader response, including state censorial institutions, first by creating a body of translational work that could be read as "great world literature" rather than "radical treatises", then by providing access to thought-provoking

\footnotetext{
${ }^{30}$ SALDANA DÍAZ. En defensa de la libertad de prensa, p. 283; BATLLÓ. Seis poetas catalanes, p. 8. "la cultura catalana [...] otra cultura".

31 Among the translations into Catalán by Carner listed in WorldCat are Molière's Francophone Le Malade imaginaire (in 1909), El burgès gentilhome (in 1918), and Burlesque Comedies (in 1981); Charles Dickens's A Christmas Carol (1918), Pickwick Papers (in 1931), Great Expectations (1934), and David Copperfield (in 1964); Lewis Carroll's Alice's Adventures in Wonderland (in 1927); Hans Christian Anderson's children's stories "Thumbelina" (in 1985) and "The Nightingale" (in 1987); Mark Twain's Tom Sawyer (in 1986); and into Spanish, Dickens's The Cricket on the Hearth (in 1902); Czech diplomat Jan Masaryk's Speeches of Jan Masaryk in America (in 1943); Czech President Edvard Benesh's War and Peace (from "the English" in 1944); and Daniel Defoe's Robinson Crusoe (in 1953).

${ }^{32}$ MURGIA. Milton in Revolutionary Hispanoamerica, p. 214.
} 
works to a readership grappling with the antecedents, experiences, and aftermath of the Second World War.

Carner's rather faithful Spanish translation of Areopagitica can certainly affect reader reception outside of its original context. As a Spanish-English bilingual reader in the U.S. and as a reader seeking the best methods of reader response to foster in my research and teaching, I was hyper-aware of the fact that I found my own reception of Milton's prose work greatly altered when reading Areopagitica in Spanish. The interplay of compassion and humor in the imprimatur section of the prose work rang more powerfully to me than it had in a long time or perhaps ever. Milton's original minimizes mention of the executive branches of censorship and of the violence enacted on individuals who take strong stands for religious and political freedoms. The potential for maleficent "men" to bear the brunt of "sharpest justice" is not erased but rather is immediately blurred with attention directed to lively "Bookes" as victims, in what doubles as a wish-fulfillment for those who have witnessed or can imagine the horrors of institutional violence. ${ }^{33}$ Elsewhere in Areopagitica, Milton lampoons the Catholic Inquisition by representing not the fearsome executors of censorial mandates but rather " 2 or 3 glutton Friers" and the risible image of Inquisitional members, "complementing and ducking each to other with their shav'n reverences". 34

My own reader responses enabled me to hypothesize perhaps with more acuity about the reader reception of Carner's and Milton's immediate audiences. While Carner's immediate Hispanophone audience possessed a greater historical distance from the early modern censorial institutions Areopagitica ridicules -in Spain, Rome, England, and elsewhere- than did Milton's immediate Anglophone audience, Carner's Ibero-Spanish audience did not possess the geographical distance from the center of the Spanish Catholic Inquisition and neither his Ibero-Spanish nor LatinAmerican audience as much of an institutional distance from it. ${ }^{35}$ Old

\footnotetext{
${ }^{33}$ MILTON. Complete Prose Works of John Milton, v. 2, p. 492.

${ }^{34}$ MILTON. Complete Prose Works of John Milton, v. 2, p. 504. Closer to home, Milton represents English "inquisiturient Bishopes" who follow papist practices as portly porters of the mandate, snatching up "the rare morsel" and buffoons who "thought to pound up the crows by shutting his Parkgate" (MILTON. Complete Prose Works of John Milton, v. 2, p. 507, 506, 520).

${ }^{35}$ Certainly, as Raymond Carr avers, by the end of its power in early nineteenth century, the Spanish "Inquisition was an ineffective irritant, slow and erratic in its procedures;
} 
institutions have a way of resurrecting in their native lands; and, while modernity has reshaped the institutional procedures for regulating social behaviors, it has not eradicated individuals' and groups' passive and active submission of their personal behaviors to social constructs.

Wai Chee Dimock calls attention to recent literary theory and practice that acknowledge the sort of immediacy that I derived from reading this non-contemporary, translated text. As Dimock describes, readers will turn "to the past not as a discrete object of knowledge but as a relational process, interactively generated through the connectivity as much as the gulf between two poles of analysis". ${ }^{36}$ This description resonates with reader reception in the form of acts of translation. Indeed, we can turn to Mario Murgia, a poet like Carner, a sensitive reader of Milton and the translator of the first Latin-American, Hispanophone translation of Areopagitica (2009). Murgia's 2009 Hispanophone translation is accurate and even captures some of Milton's style. Characteristic of the Small Great Essays [Pequeños Grandes Ensayos] series of the National Autonomous University of Mexico [Universidad Nacional Autónoma de México (UNAM)] press, the volume is accessible yet informative, especially via its seven-page preface and 108 endnotes. ${ }^{37}$ Shortly following the 2009 publication of his Hispanophone Areopagitica, Murgia published his (also excellent) Hispanophone translation of Milton's Tenure of Kings and Magistrates (1649), El titulo de reyes y magistrados (2011), in the same UNAM series. In the preface, Murgia invites readers to engage with the dense work by stirring readers to detect the prose work's larger and still relevant themes rather than historically-situated details - the useful footnotes help readers with such specific matters. In the preface, Murgia notes that Milton omits "the name of Charles I in the document", ${ }^{38}$ as a worthy translator would readily note in the word-level engagement required by the task; and he characterizes its author as "a man preoccupied not as much from the matters related to the polemical character of Charles I [beheaded the same year], but

it merely put up the price of books, forcing readers to all sorts of subterfuges in order to consume out-dated heresies" (CARR. Spain, 1808-1939, p. 77).

${ }^{36}$ DIMOCK. Editor's Column: Historicism, Presentism, Futurism, p. 260.

${ }^{37}$ The press provided the one-page long biographical chronology, which contains a few factual errors.

${ }^{38}$ MILTON. Areopagitica (2009), p. 12. "el nombre de Carlos I en el documento". 
rather the nature of tyranny and the political and moral implications, and, above all, those related to absolute government". ${ }^{39}$ I here aver that Murgia's Hispanophone Areopagitica creates a Hispanophone readership more willing and able to tackle the later and tougher El titulo.

The possible political import of both of Murgia's translations emerging near the bicentenary anniversary of Mexico's Independence from Ibero-Spanish rule (1810-1821) and centenary anniversary of the Mexican Revolution (1910-1920) is only suggested within the volumes themselves by their publication dates. But, while with Carner, we can only conjecture about the political directives of his Hispanophone translation of Areopagitica, with Murgia, Anglophone scholars can turn to his critical works, which, thankfully, chronicle such an intentional intervention in reader reception. In the "Special Issue: Milton in the Americas" of the Anglophone journal Milton Studies, Murgia points to the opportune moment for publishing his prose translations in the years surrounding 2010, "the centennial anniversary of [Mexico's] revolution against the tyrannical government of [...] Porfirio Díaz, who was eventually not beheaded but banished from the country" and the then-current high point in wide-spread "violence" and "pseudo-democratic programs and procedures" that cause Milton's Tenure to "resonate with great power in the political and literary context of contemporary Mexico and the rest of Hispanoamerica: Milton discredits all of those practices when there is no moral conviction and political honesty to support, not necessarily equality but, rather, mutuality, which lies at the heart of his argument". ${ }^{40}$

\section{Echoes, strong and barely detectable}

Hispanophone readers encounter many obstacles with hearing Miltonic echoes in world literature. This is true even of the world literature that has originated in the Hispanophone world, because of the scarcity of allusive sources in the last few decades; because no single translation

\footnotetext{
${ }^{39}$ MILTON. Areopagitica (2009), p. 9. "un hombre preocupado, no tanto por los asuntos relacionados con el polémico carácter de Carlos I, sino por la naturaleza de la tiranía y sus implicaciones políticas, morales, y, sobre todo, aquellas concernientes al gobierno absolutista".

${ }^{40}$ MURGIA. Milton in Revolutionary Hispanoamerica, p. 215-217. Murgia also published a Hispanophone translation of Milton's drama, A Mask Performed at Ludlow Castle [Comus] in 2013.
} 
of any of Milton's works, prose or poetry, is the dominant one, as was the case, for example, with the King James Version of the Bible in the Anglophone world for centuries; and because, as Murgia avers, "ever since the turn of the twentieth century, Spanish-speaking America appears to have gradually lost interest in Milton - the poet is nowadays seldom read and rarely studied in that part of the world. But it is not so much Milton's poetry as his prose that has remained in seeming oblivion there" ${ }^{41}$ When we calibrate our ears to Milton's prose, we are more likely to hear Miltonic echoes in Hispanoamerican works aimed at national self-definition and improvement. To the examples from Mexico that Murgia calls attention to, “José María Lafragua, a liberalist man of letters and founder of Mexico's National Library" and the 1990 Nobel Prize in Literature laureate Octavio Paz, we can add the Ecuadorian polyglot Juan Montalvo (1832-1889), who, in one of his many progressive essays, "Of nobility", rued the global camaraderie that he and his compatriots had not achieved because their political circumstances do not foster "a Milton, or a [Portuguese] Camoens" who might move a polity to imagine or to undertake the painstaking endeavor: "they are gone, oh!, they are gone, and I am left overwhelmed by the thousand frustrations of life". ${ }^{42}$ We also find Cuba's national hero and poet José Martí (1853-1895) invoking Milton's prose in his speeches to promote political unshackling and to justify military deaths and assassinations to achieve a liberated Cuba, and his latter-day compatriot Fidel Castro (1926-2016) citing Milton's Tenure of Kings and Magistrates in his October 1983 speech "History will absolve me". ${ }^{43}$

Many forces shape readers' access to the written works and the reading habits that enable them to witness, experience, and intervene in transformations in specific sets of literary worlds. This essay has explored only a small portion of a particularly rich if limited literary

\footnotetext{
${ }^{41}$ MURGIA. Milton in Revolutionary Hispanoamerica, p. 207-208.

${ }^{42}$ MURGIA. Milton in Revolutionary Hispanoamerica, p. 209; PICON GARFIELD; SCHULMAN. Las literaturas hispánicas: Hispanoamerica, p. 226; MONTALVO. Lecturas de Juan Montalvo, p. 2. Even the Spanish Wikipedia page mentions Montalvo's admiration for Milton, along with Byron. "un Milton, ó un Camoens"; "se fueron, ay! Se fueron, y harta falta me han hecho en mil trances de la vida".

${ }^{43}$ CASTRO. La historia me absolverá. My thanks to Stephen Fallon for alerting me to this reference. Spanish translations of Tenure were published in Spanish in 2009, translated by Guillermo Escolar Martín and Alejandro García de Mayo, and in 2012, translated by Mario Murgia.
} 
encounter of one English canonical writer in the Hispanophone world. Further exploration of the prose works by Milton and his milieu in the Anglo-Hispanic exchange remains exigent and enables all readers to contribute to setting out the most appropriate future directions of book circulation and literary interpretations, and to do so given their unique contexts and strengths.

\section{References}

BATLLÓ, José. Seis poetas catalanes. Madrid: Taurus, 1969.

BECKER, Carl L. La ciudad de Dios del siglo XVIII. Trans. Josep Carner. México, D. F.: Fondo de Cultura Económica, 1943.

BENITEZ, Rubén. Presencia de Milton en la literatura española, 17501850. Palencia: Cálamo, 2010.

BIRCH, Thomas. An Account of the Life and Writings. In: MILTON, John. A Compleat Collection of the Historical, Political, and Miscellaneous Works of John Milton. London: A. Millar, 1738. v. 1. p. i-lxiii.

BLOOM, Harold. Genius: A Mosaic of One Hundred Exemplary Creative Minds. New York: Warner, 2002.

BORGOGNI, Daniel. "Censur'd to be Much Inferiour”: Paradise Lost and Regained in Italian. In: DURAN, Angelica; ISSA, Islam; OLSON, Jonathan R. (Ed.). Milton in Translation. Oxford: Oxford University Press, 2017. p. 231-247.

CARR, Raymond. Spain, 1808-1939. Oxford: Clarendon Press, 1966.

CASTRO, Fidel. La historia me absolverá. Buenos Aires: Pedro Álvarez Tabío, 1993.

COCHRANE, Charles Norris. Cristianismo y cultura clásica. Trans. Josep Carner. México, D. F.: Fondo de Cultura Económica, 1949.

CONSUELO DE INQUISICIÓN. Indice general de los libros prohibidos y mandados expurgar. Madrid: Jose Felix Palacios, 1844. [1844 Palacios Index]

DIMOCK, Wai Chee. Editor's Column: Historicism, Presentism, Futurism. PMLA, [New York], v. 133, n. 2, p. 257-263, Mar. 2018. doi: https://doi.org/10.1632/pmla.2018.133.2.257 
DURAN, Angelica. Not either/or but rather both/and: Both Material and Electronic Archival Research in both English and Comparative Literature Graduate Courses. In: BRAYMAN HACKEL, Heidi; MOULTON, Ian Frederick (Ed.). Teaching Early Modern Literature from the Archives. New York: MLA Press, 2015. p. 162-170.

DURAN, Angelica. The Temptations of Spain in Paradise Regained. In: CORNS, Thomas; CORTHELL, Ronald (Ed.). Milton and Early Modern Catholicism. Notre Dame, IN: University of Notre Dame Press, 2017. p. 101-129.

ENGLAND AND WALES. Lord Protector (1653-1658: O. Cromwell). Manifiesto del Protector de Inglaterra hecho con acuerdo de su Consejo, declarando à fabor desta Republica, la justicia de su causa contra España. Traducido del Inglés en Español. London: H. Hills and J. Field, 1655.

ENGLAND AND WALES. Lord Protector (1653-1658: O. Cromwell). Scriptum Dom. Protectoris reipublicae Angliae, Scotiae, Hiberniae, \& c. Ex consensu atque sententiâ concilii sui editum; In quo hujus reipublicae causa contra Hispanos justa esse demonstratur. London: Henricus Hills \& Iohannes Field, 1655.

ENGLAND AND WALES. Lord Protector (1653-1658: O. Cromwell); ENGLAND AND WALES. Council of State. A Declaration of His Highness, by the Advice of His Council Setting Forth, on the Behalf of this Commonwealth, the Justice of their Cause Against Spain. London: Henry Hills and John Field, 1655.

ENGLAND AND WALES. Lord Protector (1653-1658: O. Cromwell); MILTON, John 1608-1674; THOMSON, James. A Manifesto of the Lord Protector of the Commonwealth of England, Scotland, Ireland, \& c., Published by Consent and Advice of his Council. London: A. Millar, 1738.

FALLON, Robert. Milton in Government. University Park: Pennsylvania State University Press, 1993.

FLANNAGAN, Roy. "The World All Before [Us]": More than Three Hundred Years of Criticism. In: DURAN, Angelica (Ed.). A Concise Companion to Milton. rev. Oxford: Wiley-Blackwell, 2011. p. 43-57.

FORSYTH, Neil. Sublime Conversations. Times Literary Supplement, London, p. 14-18, Dec. 2008. 
FRENCH, Joseph Milton. The Life Records of John Milton. New Brunswick: Rutgers University Press, 1949-1958. 5 v.

INSTITUTO Literario. El instituto literario del estado de Mexico en 1870. Toluca: Instituto Literario, dirigido por Pedro Martínez, 1870.

MASSON, David. The Life of John Milton: Narrated in Connexion with the Political, Ecclesiastical and Literary History of his Time. London: Macmillan, 1859-1894.

MÉXICO. Legislación mejicana, ó sea colección completa de las leyes, decretos y circulares que se han expedido desde la consumación de la independencia. Tomo que comprende de enero a diciembre de 1855. Méjico: Imprenta de Juan R. Navarro, 1855.

MILTON, John. Areopagitica. In: ELIOT, Charles W. (Ed.). The Harvard Classics. New York: Collier \& Son, 1909. v. 3. p. 199-244.

MILTON, John. Areopagitica. London: [s.n.], 1644.

MILTON, John. Areopagitica. Trans. and preface by Mario Murgia. México, D. F.: Universidad Nacional Autónoma de México, 2009.

MILTON, John. Areopagitica. Trans. Josep Carner. México, D. F.: Fondo de Cultural Económica, 1941.

MILTON, John. Areopagitica. Trans. Juan C. Catalán. Introduction and notes by Luis Blanco Vila. Madrid: Torre de Goyanes, 1999.

MILTON, John. Complete Prose Works of John Milton. Ed. Don Wolfe. New Haven: Yale University Press, 1953-1982. 8 v.

MONTALVO, Juan de. Lecturas de Juan Montalvo. Ed. Juan de Dios Uribe. Quito: Tip. de la Escuela de Artes y Oficios, 1898.

MURGIA, Mario. Milton in Revolutionary Hispanoamerica. In: SAUER, Elizabeth; DURAN, Angelica (Ed.). Milton Studies. Pittsburgh: Duquesne University Press, 2017. p. 203-222. v. 58. Special issue: Milton in the Americas.

PICON GARFIELD, Evelyn; SCHULMAN, Iván A. (Ed). Las literaturas hispánicas: Hispanoamerica. Detroit: Wayne State University Press, 1990. v. 3.

PURDUE University Libraries. Available at: $<$ https://www.lib.purdue. edu>. Accessed on: September 19, 2018. 